\title{
PERTUMBUHAN DAN SINTASAN BENIH LOBSTER AIR TAWAR (Cherax quadricarinatus) YANG DIBERI PAKAN SILASE LIMBAH VISERAL IKAN
}

\section{GROWTH AND SURVIVAL SEED FRESHWATER CRAYFISH (Cherax quadricarinatus) THE FED WITH VISCERAL FISH WASTE SILAGE}

\author{
Mahendra $^{1 *}$, Reny Nurlina Widyanti ${ }^{2)}$ \\ ${ }^{1}$ Jurusan Akuakultur, Fakultas Perikanan dan Ilmu Kelautan, Universitas Teuku Umar, Aceh Barat \\ *Korespondensi: mahendra@utu.ac.id
}

\begin{abstract}
ABSTRAK
Penelitian ini bertujuan untuk mengetahui pengaruh pemberian pakan dengan bahan dasar silase limbah visceral ikan dan persentase silase limbah visceral ikan yang baik terhadap pertumbuhan dan sintasan lobster air tawar. Rancangan percobaan yang digunakan adalah rancangan acak lengkap (RAL) dengan 5 perlakuan dan 3 kali pengulangan. Adapun Perlakuan-perlakuan tersebut yaitu T0 $=$ Pelet komersil 100\% (kontrol), $\mathrm{T} 1=$ Silase $45 \%+$ dedak $54 \%, \mathrm{~T} 2=$ Silase $55 \%+$ dedak $44 \%, \mathrm{~T} 3=$ Silase $65 \%+$ dedak $34 \%$, dan T4 $=$ Silase $75 \%+$ dedak $24 \%$. Parameter yang diamati pada penelitian ini adalah sintasan, laju pertumbuhan spesifik, efisiensi pakan, dan kualitas air. Hasil penelitian menunjukan bahwa pemberian pakan dengan berbahan dasar silase limbah visceral ikan tidak berpengaruh terhadap pertumbuhan dan sintasan lobster air tawar. Berdasarkan data kualitas air selama penelitian diperoleh kisaran suhu antara $28-30{ }^{\circ} \mathrm{C}$, derajat keasaman $(\mathrm{pH})$ dengan nilai 7 dan $\mathrm{CO} 2$ berkisar antara 0,18-0,38.
\end{abstract}

Kata kunci: Lobster, Performa, silase limbah ikan

\begin{abstract}
This study aims to determine the effect the feed with a basic material visceral fish waste silage and percentage visceral fish waste silage the best on the growth and survival of freshwater crayfis. The experimental design used was a completely randomized design (CRD) with five treatments and three replications. The treatments are $\mathrm{T} 0=$ commercial pellets $100 \%$ (kontrol), $\mathrm{T} 1=$ silage $45 \%+$ bran $54 \%, \mathrm{~T} 2=$ silage $55 \%+$ bran $44 \%, \mathrm{~T} 3=$ silage $65 \%+$ bran $34 \%$, and $\mathrm{T} 4=$ silage $75 \%+$ bran $24 \%$. The parameters observed in this study is survival, specific growth rate, feed efficiency and water quality. The results of the study showed that The feed with a basic material Visceral fish waste silage no real effect on the growth and survival of freshwater crayfish. Based on the water quality data during the study obtained the temperature range between $28-30^{\circ} \mathrm{C}, \mathrm{pH}$ with value 7 and $\mathrm{CO} 2$ ranged between $0.18-0.38$.
\end{abstract}

Keywords: Cherax, performance, fish waste silage

\footnotetext{
${ }^{1}$ Fakultas Perikanan dan Ilmu Kelautan, Universitas Teuku Umar

Korespondensi: Jurusan Akuakultur, Fakultas Perikanan dan Ilmu Kelautan, Universitas Teuku Umar, Kampus UTU Meulaboh, Alue Peunyareng 23615, Telp: +62 85260758386, email: mahendra@utu.ac.id
} 


\section{PENDAHULUAN}

Lobster air tawar (Cherax quadricarinatus) merupakan salah satu jenis udang air tawar yang berasal dari Queensland Australia. Lobster air tawar sebagai komoditas perikanan semakin popular dikalangan pembudidaya dan konsumen. Pada awalnya lobster air tawar dibudidayakan sebagaiikan hias karena bentuknya yang unikdan warnanya menarik. Namun saat sekarang ini budidaya lobster sudah mengarah ke konsumsi. Lobster air tawar ini mempunyai keunggulan bila disbanding dengan komoditas perikanan lainnya, seperti udang windu dan udang galah (Setiawan, 2006). Kelebihan Lobster air tawar antara lain persentase dagingnya tinggi, tidak mudah terserang penyakit, memijah 3-5 kali dalam satu tahun dengan fekunditas tinggi dan dapat bertahan dengan kadar DO rendah (Masser and Rouse, 1997). Selain itu teknik budidaya yang tidak sulit dan harga tinggi yang hamper menyamai Lobster air laut serta dapat dikemas tanpa menggunakan air hingga sampai ditempat tujuan dalam kondisi tetap segar (Laurence, 2001). Dilihat dari makanan kebiasaan, Lobster air tawar tergolong omnivore yaitu pemakan segala, baik tumbuhan maupun hewan. Sedangkan dilihat dari kebiasaan makan (feeding habit), Lobster air tawar termasuk bottom feeder yaitu pemakan di dasar. Selain bottom feeder lobster juga pasif dalam mecari makan, dan lebih banyak dilakukan pada malam hari atau dikenal dengan sebutan hewan nocturnal.

Pertumbuhan dipengaruhi oleh dua factor yaitu factor dalam (keturunan, sex, umur) dan factor luar (pakan) (Effendie, 1997). Pertumbuhan akan terjadi apabilamasih terdapat kelebihan energy setelah kebutuhan untuk pemeliharaan tubuh dan aktivitas terpenuhi (Afrianto dan Liviawati, 2005). Moulting atau ganti kulit merupakan proses alamiah yang terjadi pada lobster air tawar. Sebagai hewan dengan kerangka luar, lobster air tawar perlu mengganti kerangka apabila badannya tumbuh membesar. Lukito dan
Surip (2007) menyatakan bahwa frekuensi moulting pada lobster air tawar selalu beriringan dengan pertambahan umur dan tingkat laju pertumbuhan, semakin baik pertumbuhannya maka proses moulting akan sering terjadi.

Peran pakan dalam usaha budidaya sangat dominan terutama dalam budidaya yang dikelola secara intensif. Cara yang dilakukan ialah mengurangi biaya pengadaan pakan dengan mencari sumber bahan pakan yang murah, berkualitas dan tersedia setiap waktu untuk mensubstitusi dengan sumber protein lain tanpa menurunkan laju pertumbuhan.

Limbah merupakan barang yang dihasilkan dari sebuah proses dan dikategorikan sebagai bahan yang sudah tidak terpakai. Penanganan yang kurang baik dari limbah tersebut akan memberikan dampak lingkungan yang kurang baik pula, baik dalam pencemaran udara ataupun tanah pertanian. Hal ini muncul karena belum adanya teknologi tepat guna terhadap limbah limbah visceral yang berupa usus ikan merupakan salah satu alternatif sumber protein hewani yang dapat digunakan sebagai pakan. Giman (2000) menyatakan limbah visceral merupakan bahan yang dapat dimanfaatkan lebih lanjut menjadi produk yang mempunyai nilai ekonomis.

Silase merupakan produk cair yang dapat dibuat dari limbah visceral ikan yang dicairkan oleh enzim-enzim yang terdapat di dalam visceral tersebut dengan bantuan asam yang sengaja ditambahkan (Irianto, 2005). Pengolahan menjadi silase bertujuan untuk meningkatkan kualitas dari visceral ikan sehingga dapat digunakan sebagai sumber protein yang utama dalam pakan lobster air tawar. Berdasarkan hal tersebut maka dilakukan penelitian untuk melihat tentang pertumbuhan dan sintasan benih lobster air tawar (Cherax quadricarinatus) yang diberi pakan silase limbah visceral ikan. 


\section{METODE PENELITIAN}

Penelitian ini dilaksanakan pada bulan Juli hingga Agustus 2013 bertempat di Laboratorium Fakultas Perikanan dan Ilmu Kelautan Universitas Teuku Umar Meulaboh.

\section{Prosedur Penelitian}

Persiapan wadah penelitian

Wadah yang digunakan adalah akuarium sebanyak 15 unit dengan ukuran $30 \times 25 \times 20 \mathrm{~cm}^{3}$. Akuarium sebelumnya disucihamakan dengan cara direndam menggunakan kalium permanganate dosis 2 ppm selama 1 hari, setelah itu dibilas dan dibiarkan hingga kering kemudian diisi air dengan ketinggian $10 \mathrm{~cm}$. Shelter ditambahkan ke dalam tiap-tiap wadah sebagai bersembunyi.

\section{Penebaran lobster uji}

Benih yang digunakan dengan berat $1,6 \pm 0,1$ gr dan panjang $3,7 \pm 0,1 \mathrm{~cm}$ atau berumur 2 bulan. Lobster air tawar diaklimatisasi selama 7 hari dan pada akhir aklimatisasi dipuasakan selama 24 jam dengan tujuan untuk menghilangkan pengaruh sisa pakan dalam tubuh lobster air tawar. Lobster air tawar ditimbang serta diukur panjang pada awal penebaran kemudian dimasukkan ke dalam akuarium.

\section{Cara pembuatan silase}

Cara pembuatan silase diawali dengan visceral ikan dihaluskan hingga memperoleh partikel sekecil mungkin, kemudidan dtimbang sesuai kebutuhan. Campurkan nanas yang sudah dihaluskan dengan perbandingan 1:3 serta ditambahkan $\mathrm{NaCl}$ sebanyak $10 \%$ kemudian dimasukkan dalam wadah tertutup rapat dan diinkubasi selama 7 hari. Setelah itu masukkan kubis yang sudah dibersihkan ke dalam wadah fermentasi sebanyak $10 \%$ lalu diaduk secara merata dan wadah ditutup rapat, diinkubasi selama 5 hari.

\section{Cara pembuatan pelet}

Pada perlakuan T1 dengan silase $45 \%$ dan dedak $54 \%$ bila dibuat 100 gram pellet, maka dapat dilakukan perhitungan sebagai berikut:

$$
\begin{aligned}
\text { Berat silase } & =(45 / 100) \times 100 \mathrm{gr} \\
& =45 \mathrm{gr} \\
\text { Berat dedak } & =(54 / 100) \times 100 \mathrm{gr} \\
& =54 \mathrm{gr}
\end{aligned}
$$

Silase dibuat pellet dengan menambahkan dedak, tepung tapioca sebagao binder dan vitamin mineral, kemudian disiram dengan air hangat sambil diaduk hingga bisa menggumpal dan mudah terhambur. Selanjutnya dicetak dengan alat penggiling daging dan di oven dengan suhu $70^{\circ} \mathrm{C}$ selama 24 jam sesuai dengan masing-masing perlakuan.

Pengamatan kecepatan tenggelam pelet

Diawali dengan menimbang tiap-tiap pakan perlakuan seberat 0,1 gr kemudian menyiapkan air 1 liter dalam bekker glass. Setelah itu sampel pakan dimasukkan ke dalam bekker glass. Catat waktu yang diperlukan oleh pakan sejak dimasukkan hingga tenggelam di dasar bekker glass.

Pengamatan aroma dan warna pelet

Pengamatan aroma dan warna pellet dilakukan dengan memeriksa tiap-tiap pakan perlakuan dengan bantuan indera penciuman (hidung) dan indera penglihatan (mata). Hasil yang diamati dicatat.

Pemberian pakan uji

Pakan yang digunakan dalam penelitian ini adalah pakan dalam bentuk pellet. Lobster air tawar diberi pakan sebanyak 3\% dari bobot tubuhnya dan frekuensi pemberian pakan dilakukan 2 kali sehari, yaitu pagi (08.00 Wib) dan sore ( $15.00 \mathrm{Wib}$ ) sesuai perlakuan. Penentuan jumlah pakan dilakukan tiap 10 hari sekali.

Pengambilan sisa pakan

Sisa pakan setelah 2 jam diambil dengan cara menyipon dan ditampung di 
dalam baskom. Kemudian pakan diambil dengan menggunakan sendok dan disaring dengan menggunakan kertas saring. Pakan yang sudah disaring kemudian dikeringkan dan ditimbang.

Pengukuran Karbondioksida

Sampel air diambil dengan botol Winker sebanyak $250 \mathrm{ml}$. air sampel diambil sebanyak $50 \mathrm{ml}$ dengan mengunakan gelas ukur dan dituangkan ke dalam labu Erlenmeyer. Botol yang telah berisi sampel air tersebut kemudian diambil indicator phenolpethalein (pp) 0,5\% sebanyak 8 tetes, selanjutnya sampel dititrasi dengan larutan $\mathrm{Na} 2 \mathrm{CO} 30,020 \mathrm{~N}$ hingga larutan berwarna jernih. Volume larutan $\mathrm{Na} 2 \mathrm{CO} 3$ yang digunakan dicatat. Kadar karbondioksida dihitung menggunakan rumus:

$$
C O 2=\frac{V x N x B s t C O 2 x 1000}{50}
$$

Keterangan:

$\mathrm{V}=$ Jumlah $\mathrm{Na} 2 \mathrm{CO} 3$ yang terpakai $(\mathrm{ml})$

$\mathrm{N}=$ Normalitas $\mathrm{Na} 2 \mathrm{CO} 3(0,020 \mathrm{~N})$

Bst $=$ Bobot setara karbondioksida (22)

$50=$ Volume air sampel

Pengukuran $\mathrm{pH}$

Kertas indikator $\mathrm{pH}$ universal dicelupkan ke dalam air pada wadah pemeliharaan. Kemudian perubahan warna yang terjadi pada kertas tersebut dicocokkan dengan warna standar nilai $\mathrm{pH}$ dan hasilnya dicatat.

Pengukuran temperatur

Temperatur air dikur dengan menggunakan termometer air raksa dengan ketelitian $1{ }^{\circ} \mathrm{C}$. Termometer dengan bantuan tali dicelupkan ke dalam air pada wadah pemeliharaan hingga air raksa konstan dan tidak bergerak dan hasilnya dicatat.

\section{Parameter Uji}

Sintasan

\section{$\mathrm{SR}=\mathrm{N} t \mathrm{No} \times 100 \%$}

Keterangan :

$\mathrm{SR}=$ Sintasan $(\%)$

$\mathrm{Nt}=$ Jumlah lobster pada waktu $\mathrm{t}$ (individu)

No = Jumlah lobster pada awal percobaan (individu)

Laju Pertumbuhan Spesifik (SGR)

$$
\mathrm{SGR}=\frac{\operatorname{Ln} \mathrm{Wt}-\operatorname{Ln} \mathrm{W} 0}{\mathrm{t}} \times 100 \%
$$

Keterangan:

SGR = Laju pertumbuhan spesifik

$\mathrm{Ln} \mathrm{Wt}=$ Berat lobster akhir penelitian

Ln W0 = Berat lobster awal penelitian

$\mathrm{t}=$ Waktu penelitian (lama penelitian)

\section{Efisiensi Pakan (EP)}

$\mathrm{EP}=\frac{(\mathrm{Wt}-\mathrm{W} 0)+\mathrm{D}}{\mathrm{F}}$

Keterangan:

$\mathrm{EP}=$ Efesiensi pakan

$\mathrm{F}=$ Jumlah pakan yang dihabiskan

$\mathrm{W}_{\mathrm{t}}=$ Berat lobster pada akhir pemeliharaan $(\mathrm{g})$

$\mathrm{D}=$ Berat lobster mati selama pemeliharaan $(\mathrm{g})$

$\mathrm{W}_{\mathrm{o}}=$ Berat lobster pada awal pemeliharaan $(\mathrm{g})$

\section{Rancangan Penelitian}

Metode yang digunaka dalam penelitian ini adalah metode eksperimental menggunakan rancangan acak lengkap (RAL) dengan 5 perlakuan diulang sebanyak tiga kali.

T0 $=$ Pelet komersil 100\% (kontrol)

$\mathrm{T} 1=$ Silase $45 \%+$ dedak $54 \%$

$\mathrm{T} 2=$ Silase $55 \%+$ dedak $44 \%$

$\mathrm{T} 3=$ Silase $65 \%+$ dedak $34 \%$

$\mathrm{T} 4=$ Silase $75 \%+$ dedak $24 \%$ 


\section{Analisis Data}

Data yang diperoleh berupa pertumbuhan dan sintasan lobster uji serta efisiensi pakan yang diukur dengan menggunakan ANOVA. Apabila hasil uji $\mathrm{F}$ menunjukkan hasil yang berbeda nyata atau sangat nyata, maka dilanjutkan dengan uji beda nyata terkecil (BNT) untuk membandingkan antar masing-masing perlakuan.

\section{HASIL DAN PEMBAHASAN}

\section{Pengamatan Fermentasi Pada Pembuatan} Silase

Hasil pengamatan fermentasi pada pembuatan silase dapat dilihat pada Tabel 1. Tabel 1. Nilai $\mathrm{pH}$ dan suhu silase proses fermentasi

\begin{tabular}{ccc}
\hline Hari ke- & $\mathrm{pH}$ & Suhu $\left({ }^{0} \mathrm{C}\right)$ \\
\hline 1 & 5 & 33 \\
7 & 5 & 29 \\
12 & 5 & 28 \\
\hline
\end{tabular}

Berdasarkan Tabel 1. Nilai $\mathrm{pH}$ selama proses fermentasi sebesar 5 yang berarti silase tersebut bersifat asam. Menurut Trijoko et al., (2007) menyatakan adanya peningkatan kinerja enzim proteolitik yang disebabkan karena penurunan drajat keasaman akan mendegradasi protein menjadi ikatan peptide rantai pendek dan asam amino bebas sehingga akan meningkatkan kecernaan dari protein yang terkandung pada bahan baku.

Menurut Bath et al., (1985) dalam Haetami et al., (2006), pembentukan asam asetat berlangsung selama 3-5 hari pertama dan dilanjutkan dengan pembentukan asam laktat, dimana nilai $\mathrm{pH}$ mencapai 4. Pada proses silase secara biologis bakteri asam laktat akan mengubah gula menjadi asam organik yang mengakibatkan terjadinya perubahan $\mathrm{pH}$.

Bakteri asam laktat akan menggunakan karbohidrat yang terlarut dalam air untuk menghasilkan asam laktat dan berperan dalam penurunan $\mathrm{pH}$ silase. Selama proses fermentasi asam laktat yang dihasilkan akan berperan sebagai zat pengawet sehingga dapat menghindarkan pertumbuhan organisme pembusuk (Ratnakomala et al., 2006).

\section{Sintasan}

Berdasarkan analisis variansi terhadap sintasan lobster air tawar dengan pemberian perlakuan pakan silase limbah visceral ikan tidak memberi pengaruh yang nyata $(\mathrm{F}$ hit < $F$ tab 0,05 dan 0,01).

Persentase sintasan lobster air tawar masing-masing perlakuan (Gambar 1) adalah $\mathrm{T} 0=86,7 \pm 23,1 \quad \% ; \quad \mathrm{T} 1=100 \%$; $\mathrm{T} 2=93,3 \pm 11,5 \%$; $\mathrm{T} 3=100 \%$; dan $\mathrm{T} 4=100 \%$. Hasil analisis rata-rata sintasan lobster air tawar menunjukkan hasil tidak berbeda nyata antar perlakuan sehingga pemberian silase dalam pakan buatan tidak memberikan pengaruh terhadap sintasan benih lobster air tawar.

Mortalitas dipengaruhi oleh faktor yang berasal dari dalam yaitu genetika, umur dan kemampuan untuk menyesuaikan diri dengan lingkungan. Sedangkan faktor luar adalah kompetis antar inidividu, padat penebaran, pakan yang tidak mencukupi serta faktor kualitas air (Kurniasih, 2008).

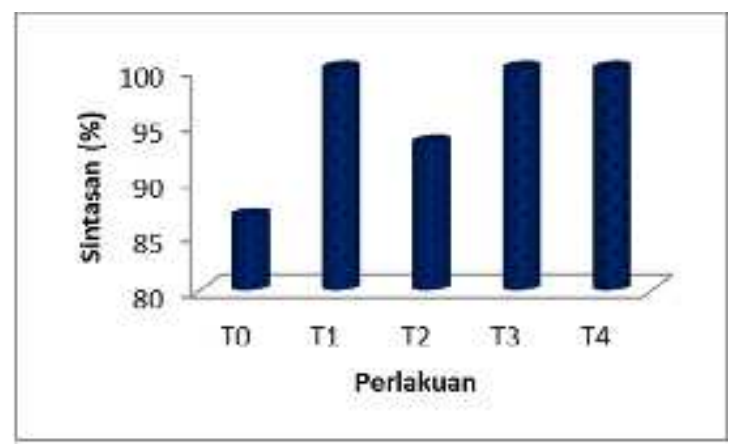

Gambar 1. Histogram persentase rata-rata kelangsungan hidup lobster air tawar

Tingkat sintasan lobster air tawar pada masing-masing perlakuan selama penelitian berada pada kisaran yang baik, karena sesuai dengan pernyataan Fitria (2010) menyatakan bahwa tingkat sintasan yang baik adalah 
lebih dari 50\%. Hal ini diduga karena nilai parameter kualitas air yang berada pada kondisi ideal bagi pertumbuhan benih lobster air tawar.

\section{Laju Pertumbuhan Spesifik}

Hasil analisis laju pertumbuhan spesifik diketahui bahwa perlakuan pemberian pakan silase limbah visceral ikan pada lobster air tawar tidak berpengaruh nyata (F hit $<\mathrm{F}$ tab 0,05 dan 0,01 ).

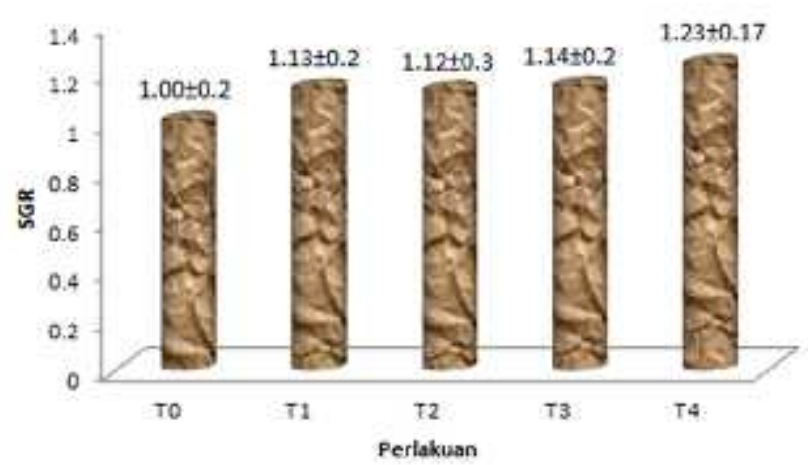

Gambar 2. Histogram laju pertumbuhan spesifik rata-rata lobster air tawar

Berdasarkan Gambar 2. Laju pertumbuhan spesifik rata-rata lobster air tawar pada masing-masing perlakuan adalah $\mathrm{T} 0=1,00 \pm 0,23 \quad \% ; \quad \mathrm{T} 1=1,13 \pm 0,27 \%$; $\mathrm{T} 2=1,12 \pm 0,23 \% ; \quad \mathrm{T} 3=1,14 \pm 0,2 \% ; \quad$ dan $\mathrm{T} 4=1,23 \pm 0,17 \%$. Menurut Pinandoyo (2005), protein yang berkualitas baik akan mampu memberikan pertumbuhan yang baik pula bagi organisme budidaya jika komposisi dan ketersediaan asam amino yang dibutuhkan bagi pertumbuhan organisme tersebut tecukupi. Menurut Halver (1987) dalam Fitria (2010), nilai laju pertumbuhan spesifik yang baik sedikitnya $1 \%$. Pertumbuhan pada lobster air tawar juga ditandai dengan pertambahan panjang. Pertambahan panjang rata-rata lobster air tawar yang diberi perlakuan pakan yang berbeda ini mengalami peningkatan seiring dengan bertambahnya waktu pemeliharaan. Effendie (1997) menyatakan bahwa pertumbuhan merupakan pertambahan ukuran panjang atau berat dalam suatu waktu.

\section{Efesiensi Pakan}

Berdasarkan hasil analisis variansi terhadap efisiensi pakan menunjukkan tidak adanya pengaruh nyata ( $\mathrm{F}$ hit $<\mathrm{F}$ tab 0,05 dan $0,01)$. Hasil pengamatan efesiensi pakan lobster air tawar yang diberi perlakuan disajikan pada gambar 3 .

Hasil penelitian terlihat nilai efesiensi pakan secara berurutan adalah $\mathrm{T} 0=0,25 \pm 0,2$; $\mathrm{T} 1=0,088 \pm 0,02 ; \mathrm{T} 2=0,13 \pm 0,11 ; \mathrm{T} 3=$ $0,082 \pm 0,01 ;$ dan T4 $=0,09 \pm 0,001$. Persentase silase pada masing-masing perlakuan sebagai pakan lobster air tawar tidak menunjukkan pengaruh yang nyata terhadap nilai efesiensi pakan.

Menurut Buhari (1994), efesiensi pemberian pakan merupakan perbandingan antara pertambahan berat badan dengan jumlah pemberian pakan selama penelitian. Efesiensi pakan pada benih lobster air tawar terlihat masih rendah, hal ini diduga karena lobster termasuk jenis hewan yang pertumbuhannya lambat.

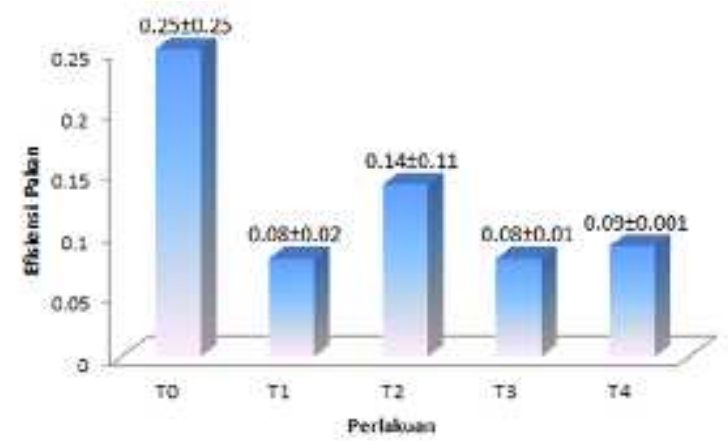

Gambar 3. Histogram rata-rata efisiensi pakan lobster air tawar

Semakin kecil jumlah pakan yang dikonsumsi maka protein yang terkandung dalam pakan pun akan semakin rendah dan pemanfaatannya menjadi protein tubuh akan semakin berkurang (Basyari dan Tanaka, (1985) dalam Pinandoyo, 2005). Nilai efesiensi pakan tidak hanya tergantung pada jumlah pakan yag diberikan tetapi juga dipengaruhi oleh beberapa faktor diantaranya padat tebar, umur, berat setiap individu, suhu dan cara pemberian pakan (Huet, 1971). 


\section{Kecepatan Tenggelam dan Daya Larut Pelet}

Kecepatan tenggelam dan daya larut dapat digunakan untuk menentukan kualitas pakan. Berdasarkan hasil pengamatan mengenai kecepatan tenggelam dan daya larut dari masing-masing perlakuan pellet yang terbuat dari silase dapat dilihat pada Gambar 4.

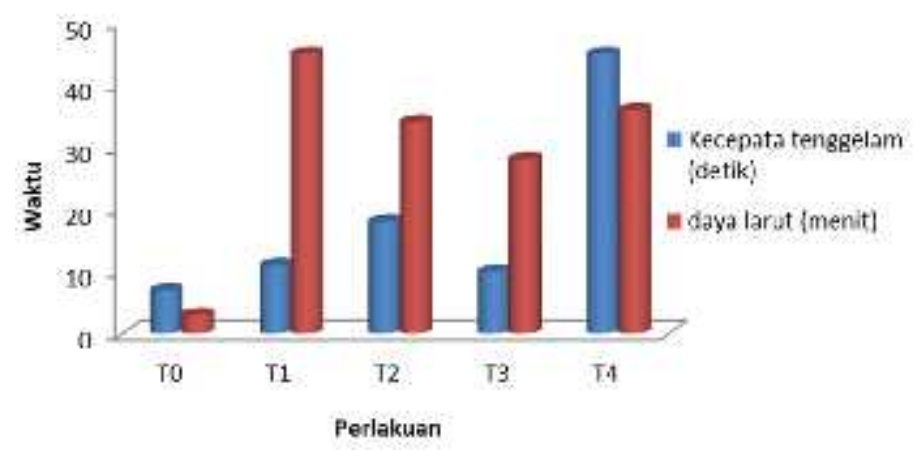

Gambar 4. Histogram Kecepatan Tenggelam dan daya larut pelet

Berdasarkan Gambar 4, kecepatan tenggelam yang tercepat pada perlakuan silase $65 \%$ + dedak $34 \%$ (T3) dan kecepatan tenggelam paling lama pada perlakuan silase $75 \%$ + dedak $34 \%$ (T4). Sedangkan daya larut tercepat pada perlakuan silase $65 \%+$ dedak $34 \%$ (T3), dan daya larut paling lama pada perlakuan silase $45 \%+$ dedak $54 \%$ (T1).

Untuk membandingkan kekompakan dan keutuhan bentuk pellet dilakukan pengujian terhadap kecepatan tenggelam dan daya apung pellet di dalam air, sehingga ketahanan pellet di dalam air menggambarkan kekompakan pellet tersebut. Hal ini sesuai dengan pendapat Kamaruddin et al., (2008), bahwa kehalusan bahan baku dalam pembuatan pakan dapat mempengaruhi kepadatan pakan (ketahanan pakan dalam air). Pellet yang diperuntukkan bagi udang lobster sebaiknya mempunyai ketahanan di dalam air yang lebih lama, semakin lama waktu yang dibutuhkan untuk menghancurkan pellet berarti semakin baik kualitas pellet tersebut (Afrianto dan Liviawati, 2005).

\section{Warna dan Aroma}

Hasil pengamatan mengenai warna dan aroma dari masing-masing perlakuan dapat dilihat pada Tabel 2.

Tabel 2. Warna dan aroma pakan setiap perlakuan

\begin{tabular}{lll}
\hline Perlakuan & Warna & Aroma \\
\hline T0 & Coklat muda & Ikan \\
T1 & Coklat muda & tape \\
T2 & Coklat muda & tape \\
T3 & Coklat tua & tape \\
T4 & Coklat tua & tape \\
\hline
\end{tabular}

Berdasarkan Tabel 2. Warna coklat muda terdapat pada perlakuan T0, T1 dan T2. Sedangkan warna coklat tua pada perlakuan T3 dan T4. Aroma ikan terdapat pada perlakuan T0, hal ini disebabkan karena persentase protein yang tinggi yaitu sebesar $30 \%$, sedangkan aroma tape pada perlakuan T1, T2, T3 dan T4. Hal ini disebabkan karena adanya proses fermentasi saat pembuatan silase.

\section{Kualitas Air}

Secara umum untuk membandingkan hasil penelitian pengukuran kualitas air selama penelitian disajikan pada Tabel 3 berikut ini:

Tabel 3. Nilai parameter kualitas air selama penelitian

\begin{tabular}{llllll}
\hline \multirow{2}{*}{ Parameter } & \multicolumn{2}{l}{ Perlakuan } & & & \\
& T0 & T1 & T2 & T3 & T4 \\
\hline Suhu $\left({ }^{\circ} \mathrm{C}\right)$ & $28-$ & $28-$ & $28-$ & $28-$ & $28-$ \\
& 30 & 30 & 30 & 30 & 30 \\
$\mathrm{pH}$ & 7 & 7 & 7 & 7 & 7 \\
$\mathrm{CO} 2$ & 0,38 & 0,18 & 0,27 & 0,24 & 0,23 \\
$(\mathrm{mg} / \mathrm{L})$ & & & & & \\
\hline
\end{tabular}

Hasil pengukuran parameter kualitas air dilakukan pada hari ke-10, ke-20 dan ke30 setiap perlakuan selama penelitian menunjukkan bahwa suhu berkisar antara 28$30{ }^{\circ} \mathrm{C}$. Hal ini tidak berbeda dari pernyataan Iriana et al., (2006) bahwa suhu optimal bagi benih lobster air tawar ialah $28{ }^{\circ} \mathrm{C}$, sebab pada suhu tersebut benih lobster mengalami tingkat adaptasi paling bail dalam menggunakan energy yang ada untuk pertumbuhan. 
Menurut Wardoyo dan Djokosetiyanto (1988), suhu air dapat mempengaruhi sintasan, pertumbuhan morfologis, siklus reproduksi, tingkah laku, pergantian kulit atau moulting dan metabolism tubuh. Hal ini juga didukung oleh pernyataan Santoso (2008), bahwa pada suhu yang rendah proses metabolisme pada tubuh lobster air tawar rendah dan semakin tinggi suhu maka proses metabolism semakin tinggi pula.

Nilai $\mathrm{pH}$ merupakan salah satu sifat kimia perairan yang secara langsung berpengaruh terhadap laju pertumbuhan dan sintasan (Boyd, 1990). Nilai pH selama pemeliharaan berada pada kisaran yang mampu mendukung pertumbuhan benih lobster air tawar. Sesuai dengan penelitian Kurniasih (2008), pH yang sesuai untuk mendukung kehidupan lobster yang layak berkisar antara 6,5-9,0. Nilai $\mathrm{pH}$ air untuk pertumbuhan lobster air tawar berkisar antara 7-8. Jika $\mathrm{pH}$ kurang dari kisaran tersebut lobster air tawar akan mengalami stres (Suryaningrum et al., 2007).

Rata-rata kadar $\mathrm{CO} 2$ selama pemeliharaan berkisar antara $0,18-0,38 \mathrm{mg} / \mathrm{l}$. Menurut Suryaningrum et al., (2008), CO2 dihasilkan sebagai oksidasi senyawa organik yang berasal dari makanan selama proses respirasi. Secara teknis upaya perbaikan kualitas air dilakukan dengan cara penyiponan dan pergantian air secara berkala sehingga kestabilan parameter kualitas air dapat terjaga. Dari pengamatan kualitas air (Tabel 3) masih dalam kisaran yang layak bagi kehidupan lobster air tawar.

\section{KESIMPULAN}

Dari hasil penelitian dapat di simpulkan sebagai berikut:

1. Pemberian pakan berbahan dasar silase limbah visceral ikan tidak berpengaruh terhadap pertumbuhan dan sintasan lobster air tawar.

2. Tidak didapatkan persentase silase limbah visceral ikan yang paling baik untuk pertumbuhan dan sintasan lobster air tawar.

\section{UCAPAN TERIMA KASIH}

Riset penulis didanai secara mandiri, dan ucapan terima kasih kepada Instansi Universitas Teuku Umar khusunya LPPM dan Penjaminan Mutu serta Program Studi Akuakultur Fakultas Perikanan dan Ilmu Kelautan.

\section{DAFTAR PUSTAKA}

Afrianto, E dan Liviawati. 2005. Pakan Ikan. Kanisius. Yogyakarta

Boyd, C.E. 1990. Water quality manajemen for pond fish culture. Elsevier Scientific Publishing Company. Amsterdam. Oxford. USA. $482 \mathrm{pp}$

Buhari, D. 1994. Silase Limbah HasilPerikanan Untuk Pakan Ikan Mas (Cyprinus carpio). Terubuk. XX, 60: 52-60

Effendie, M. I. 1997. Metode Biologi Perikanan. Yayasan Dewi Sri, Bogor, $112 \mathrm{hlm}$.

Fitria, S. 2010. Upaya Memacu Laju Pertumbuhan dan Kelangsungan Hidup Benih Ikan Bawal Tawar (Colossoma sp) Dengan Menggunakan Pakan Yang Berbeda. Skripsi. Fakultas Sains Dan Teknik. Universitas Jenderal Soedirman Giman. 2000. Pemanfaatan Limbah Perikanan dalam Rangka Pemberdayaan Masyarakat Nelayan. Majalah Ilmiah Pembangunan dan Pengembangan Kelautan 7:33-39

Haetami, K., Susangka, I., dan Maulina, I. 2006. Suplementasi Asam Amino Pada Pelet Yang Mengandung Silase Ampas Tahu Dari Implikasinya Terhadap Pertumbuhan Benih Ikan Nila Gift (Oreochromis niloticus). Universitas Padjadjaran. Bandung

Huet, M. 1971. Text Book of Fish Culture, Eyre and Spottis Woodle Ltd. London.

Iriana, I., Hadie, W., dan Sianipar. 2006. Suhu Optimum Untuk Laju Pertumbuhan Dan Sintasan Benih Lobster Air Tawar (Cherax quadricarinatus). Jurnal Riset Akuakultur, 1: 67-72 
Irianto, H.E. 2005. Perbaikan Teknologi Produksi pada Industri Tepung Ikan Di Indonesia. Jurnal Riset Akuakultur P:29

Kamaruddin., Usman., dan Tangko, A.M. 2008. Perisapan dan Penyusunan Bahan Baku Lokal Untuk Formulasi Pakan Ikan. Media Akuakultur. 3: 150-156

Kurniasih, T. 2008. Evaluasi Pertumbuhan, Sintasan dan Nisbah Kelamin Huna Biru (Cherax albertisii) dan Red Claw (Cherax quadricarinatus) dengan Pemberian Pakan Alami dan Pakan Buatan. Jurnal Ilmu-Ilmu Perairan dan Perikanan Indonesia, 15: 61-68

Kurniasih, T. 2008. Lobster Air Tawar (Parastacidae: Cherax), Aspek Biologi, Habitat, Penyebaran, dan Potensi Pengembangannya. Akuakultur, 3: 3135

Laurence, C. 2001. Yabbies (Cherax albinus) A Andbook For Farmers and Investor. Fisheries Department of WA. 6 pp.

Lukito, A dan Surip, P. 2007. Panduan Lengkap Lobster Air Tawar. Penebar Swadaya. Jakarta

Masser, M.P and Rouse, D.B. 1997. Australian Red Claw Crayfish. Southern Regional Aquaculture Center, 244: $1-8$

Pinandoyo. 2005. Penggunaan Berbagai Dosis Silase Darah Sebagai Sebagai Diet Pakan Terhadap Pertumbuhan dan Kelangsungan Hidup Ikan Baronang (Siganus guttatus Bloch). Ilmu Kelautan. 10: 185-190

Ratnakomala, S., Ridwan, R., dan Kartika. 2006. Pengaruh Inokulum Lactobacillus Plantarum 1A-2 dan 1BL-2 Terhadap Kualitas Silase Rumput Gajah (Pennistum purpureum). Biodiversitas. 7:131-134

Santoso, M. 2008. Pertumbuhan, Sintasan dan Efesiensi Pakan Pada Lobster Air Tawar (Cherax quadricarinatus) Yang Diberi Pakan dan Peneduh Yang Berbeda. Tesis. Program Pasca Sarjana. Universitas Jenderal Soedirman. Purwokerto

Setiawan, C. 2006. Teknik Pembenihan dan Cara Cepat Pembesaran Lobster Air Tawar. Agromedia Pustaka. Jakarta

Suryaningrum, T.D., Ikasari, D., dan Syamdidi. 2008. Pengaruh Kepadatan dan Durasi Dalam Kondisi Transportasi
Sistem Kering Terhadap Kelulusan Hidup Lobster Air Tawar (Cherax quadricarinatus). Jurnal Pascapanen dan Bioteknologi Kelautan dan Perikanan, 3:171-180

Suryaningrum, T.D., Ikasari, D., dan Syamdidi. 2008. Teknologi Penanganan dan Transportasi Lobster Air Tawar. Squalen. 2: 37-42

Trijoko., Fairus, A., dan Yudisthira. A. 2007. Pengaruh Penambahan Silase Artemia Pada Pakan Buatan Terhadap Pertumbuhan dan Kelulusanhidupan Pascalarva Udang Vaname. Aquaculture Indonesiana. 8: 17-26

Wardoyo, S.T.H dan Djokosetyanto, D. 1988. Pengelolaan Kualitas Air Tambak. Makalah Seminar Memacu Keberhasilan dan Pengembangan Usaha Pertambakan. Bogor. 15 pp. 